\title{
Influence of Roman History on Shakespeare's Works
}

\author{
Ioanna-Soultana Kotsori \\ University of Peloponnese, Faculty of Humanities and Cultural Studies, Kalamata
}

\author{
Kyriakos Manolis ${ }^{1}$ \\ National and Kapodistrian University of Athens, School of Philosophy
}

Received 29 June 2018 - Revised 10 July 2018 • Accepted 18 July 2018

\begin{abstract}
Shakespeare is one of the greatest English writer, whose works have been translated into most languages of the world. He wrote most of his works between 1589 and 1613, during the Renaissance. Shakespeare's influence came from the classical and the Roman world, especially from the theatrical tradition. It was also influenced by the Latin writers and borrowed a lot of them. Shakespeare's works relate to Roman history and are associated with the Latin poets, but also with the Greek historians and Socratic philosophers. The Roman elements govern the work of Shakespeare. Indeed, blood and violence are typical of Roman works, as is the struggle of clans and citizens of ancient Rome. In Shakespeare's era, the palace intrigue was not lacking, while the theater was popular as a political manipulation of the masses.
\end{abstract}

Keywords: Roman history, Roman figures, Renaissance, tragedies, Roman drama, Latin authors.

\section{Introduction}

Shakespeare was an English poet but also a playwright. Indeed, he is considered to be the greatest writer in the English language and one of the most important dramaturgists in the world (Wells, 1997: 399). His surviving works consist mainly of 38 theatrical plays, which have been translated into most languages of the world and have been more often interpreted by the works of any author (Craig, 2003: 3). He wrote most of his works between 1589 and 1613 (Kastan, 1999: 37).

During the Middle Ages, Greek and Roman drama fell into obscurity and the new tradition revolved around the Medieval Church, so the drama stayed behind. During the Renaissance, however, the classical plays survived. The greatest impact on drama during the Renaissance came from Rome and not from Greece. So Shakespeare's influence came from the classical and the Roman world, especially from the theatrical tradition. It was also influenced by the Latin writers and borrowed a lot of them. Specifically, it was influenced by Ovidius, Plafto, Seneca, Plutarch, and Virgilius.

${ }^{1}$ The author is PhD student at the National and Kapodistrian University of Athens, School of Philosophy.

(C) Authors. Terms and conditions of Creative Commons Attribution 4.0 International (CC BY 4.0) apply. Correspondence: Ioanna-Soultana Kotsori, e-mail: ioannakotsori@gmail.com. 
These Latino writers are defined by some characteristic features. Latin author Ovidius "hits" the Europe of Renaissance. Senecas, a classic tragic writer, has produced blood-stained stories about revenge and torture during the Renaissance. Plutarch's Parallel lives are a major source of Roman history (Taylor, 1994: 283-314).

The Roman elements govern the work of Shakespeare. Indeed, blood and violence are typical of Roman works, as is the struggle of clans and citizens of ancient Rome. Suicide is also an important Roman custom. Just as the Romans are presented as conscientious theatrical as well as historical, and they are well acquainted with the characters they are in touch with and analyze them in depth. Shakespeare's England was nationalistic and imperial. On the other hand, Shakespeare's Rome was more than an ancient city. Rome is the incarnation of the era of Virgilius. It has invasions, hunger, betrayal, rebellion, adultery, intertwined reactions to the history of human civilization.

In other words, in Rome there are imperfections and innate corruption. Shakespeare at this time was in England behind the kingdom of Elizabeth and Jacob (Chambers, 1923: 208209). Let's note that the political situation of the time was not just morbid. The palace intrigue was not lacking, while the theater was popular as a political manipulation of the masses.

\section{Latin and ancient Greek literature in Shakespeare's work}

Each Shakespeare's work is also influenced by a representative of Latin or ancient Greek literature. Shakespeare's works relate to Roman history and are associated with the Latin poets, but also with the Greek historians and Socratic philosophers. Here is the role of Shakespeare, who is studying the above. In the work of Romeo and Juliet, Shakespeare borrows tragic love stories from antiquity, one of which is the love story of Pyramos and Thisbe. This myth derives from Greek mythology. This myth then evolved by the Romans and appeared in Ovidius (Metamorphoseis, 4, 55-166). The common point of this myth with Shakespeare's work is the final tragic ending of Piramus and Thisbe, likewise in Romeo and Juliet.

In his work also Romeo and Juliet, Shakespeare is influenced by the Metamorphoseis of Ovidius, where there are similar correspondences and parallelisms with the history of Shakespeare's work (Crabbe, 1981: 274-327). All the stories of human Metamorphoseis are erotic and enriched with elements of passion, which are also evident in the work of Shakespeare Romeo and Juliet. Ovidius was a Latin poet, born in $43 \mathrm{BC}$ and died in $17 \mathrm{AD}$. This one has a Greek background, but as we progress chronologically, the use of Greek is diminishing. His Metamorphoseis consist of fifteen books.

Indeed all 15 books of his Metamorphoseis are a mixture of scenes. These scenes are mythical, fantastic, scenes that have to do with Homer's literature, scenes of Rome's tragedy, erotic scenes (Von Albrecht, 1997: 735-7), to complete and complete this work with its deposition Caesar. The scenes that converge there are Greek and Roman. Also in the presentation of this work, Shakespeare is influenced by the Ephesians $(1,1-8)$, a novel of Xenophon of Ephesus. There are similarities in lover separation and the filter that causes dead sleep. The only surviving work of the Ephesian, tells the story of Anthia and Avrokomi. It is also considered to be a great work for the study and development of the evolution of the Greek novel, and an important ancestor of medieval novels (romances).

In Shakespeare's work Antonios and Cleopatra seems to be influenced by the Latino writer Virgilius and the work of Aeneid. In this work we have the history of Dides and Aeneas. Beyond this mature love story, common points in Shakespeare's and Aeneid's specific work are passionate life, post-mortem life, protest for the values of Rome, and the political necessity of marriage. 
This epic work, which has been described as the most important one ever written in Latin, links Rome with Troy and its legends while at the same time praising the "traditional" Roman virtues and "legitimizing" the Julian dynasty as originating from the founders, heroes and gods of Rome and Troy. The Aeneid is made up of twelve books, the first six have to do with Aeneas, the central protagonist, whose adventures we see from Troy until he reaches Italy, influenced by Homer's Odyssey.

While the other six books refer to the war of Troy and the Latins, influenced by the Iliad. Virgilius as a Latin poet incorporated into the work of many myths about the face of Aeneas, which is nothing but mythical. Virgilius, however, was born in $70 \mathrm{BC}$ with $19 \mathrm{AD}$, he cannot be influenced by the political conditions of his time and beyond his poetic qualities and the incorporation into his works of mythical elements, not to incorporate them into them, in particular the work of Aeneid associated with Shakespeare's work, and true historical facts. Moreover, this task was commissioned from August. Virgilius's life begins in the years of Pompey's occupation, in $70 \mathrm{AD}$. Then Pompey keeps the East and Caesar the West.

When Caesar is assassinated, Virgilius was 26 years old, he lives the civil wars in Rome, and he sees with his own eyes in August bringing peace to the Roman Empire and enjoying it. Therefore, apart from the fact that Virgilius's work shares points with Antonios and Cleopatra of Shakespeare, it is a Roman work and not only a text of European civilization. Also, Shakespeare in this work as regards the performance of the leading physiognomy and the politics of Octavianus Caesar was influenced by Horatio (Albrecht, 1997: 626-633).

In the plot of Shakespeare's work Coriolanus, the writer's influence is influenced by the myth of Menenius, the myth of Aesop's belly, used by Shakespeare through Coriolanus mouth as an example to show that all at the same time must work the same and right for to achieve something right, in this case our work will have people and power to operate equally.

\section{Shakespeare's works and the Roman figures}

The following tragedies associated with Roman history: First we meet Titus Andronicus, which was published in 1594. Then follows the work of Romeo and Juliet, which was published in 1597. Then Julius Caesar followed in 1599. It follows the work of Troilos and Chryssidas, which was written in 1602 (mythological work). Coriolanus is written between 16051608. While the other work of Antonios and Cleopatra, we know that it was written in 1607. To complement his work may be added that wrote and mythological works in Greece (Timon of Athens, Troilus and Chryseis, Venus and Adonis, Midsummer night's dream), but not so many works for Athens, perhaps because he did not know enough about it (Creek, 2014: 9-13).

\subsection{Titus Andronicus}

Titus Andronikus was the Roman General who distinguished himself in the wars against the Goths. The Goths make their presence felt in the Roman Empire in the 3rd century, and find the Roman state in a political, military and economic crisis. At that time between 379395 Emperor Theodosius I acted (Gibbon, 1932: 895). The Goths now plunder Thrace and Adrianople. Thus, the new emperor of the eastern Roman state, Theodosius I, came in concert with the Goths and allowed them to settle in the Roman state with the obligation to provide military units to them during the Roman wars (Carr, 2015: 40-43). Between 527-565 he acted Justinian A'37, who inherited from his predecessor military commitments on the eastern border, and of course the Goths within their borders.

The Goths reiterate in 537, specifically on 27 December 537, their reappearance. Specifically, when the temple of Hagia Sophia is inaugurated in Constantinople, Rome is besieged 
by the Goths. In 552 the Goths crashed into the Bust Gallorum of Umbria (Haldon, 2003: 17-19). Seeing the Romans' victories over the Goths, we can place Titus Andronikus, at the time of Theodosius I, at the beginning of his reign with his victories against the Goths, or in the time of Justinian I, between 537-552, victories of the Roman Empire against the Goths are noted.

Titus Andronikus was the first tragedy that William Shakespeare wrote, written between 1593 and 1594, probably in collaboration with George Peele. It is thought to be Shakespeare's first tragedy, and is often seen as his attempt to emulate the violent and bloody revenge plays of his contemporaries, which were extremely popular with audiences throughout the 16th century (Cook, 1981: 13). It was first published in 1623, and it is based on real historical events and people (Mowat, 2014: 13). This work was a successful work of Shakespeare, which before 1623 had seen success. It was, of course, a work of the poet who had not yet had such maturity, that of his later works. It was an early work without the appropriate maturation. Specifically, the poet wishes to place in his work so much information, so many varied emotions diffused, elements that suggest exaggeration and characterize his work as a genius.

In this particular work Shakespeare seems to be hooked by the Latin writers Seneca and Ovidius, but also to use in his work subjects of Greek mythology, the habit of the Renaissance. The general climate of the era in which he publishes the work of Titus Andronicus is governed by the heavy veil of the Middle Ages. But the poet wants to escape this dark period and follow the first steps of the Renaissance. As far as the technique of this particular project is concerned, it is influenced to a large extent by Seneca, and uses artfully from scenery tricks. The plot of tragedy now has as its main source the virtue which contrasts with evil, while revenge is the one that gives the final touch (Sonnestatter, 2008: 3, 16).

\subsection{Julius Caesar}

Gaius Julius Caesar (100 BC - 44 BC) was a Roman politician, general and noted writer of Latin historiography. After the collapse of the Roman Republic he helped rise of the Roman Empire. In 59 BC he was elected to Rome. It is worth noting that Caesar was with the proletarian side and not with the aristocracy of the Senate. The climate of the era was governed by corruption and ballot. Plutarch considers him superior to all the Roman generals until then, judging him from the adverse environmental conditions of the places where he fought, the extent of the countries he conquered, the crowd and the passion of the enemies, and the loyalty he had in his army (Plutarch, Caesar, 15-16).

The work of Shakespeare Julius Caesar was written between 1599-1600. This work represents the poetic maturation of the poet, not his youthful work, but he is in his full maturity and in his overall whole perfectly constructed. This is the political backstamps that exist in a state, as well as the power problems. Julius Caesar of Shakespeare is influenced by Plutarch, whom he uses as his source (Lippincott, 1913: 394). Specifically, in this work two points prove that his work is clearly influenced by Plutarch. The information that is part of the main theme of his work ensures a continuous flow, drawing on the work of Plutarch, in particular by the Parallel lives.

He is also influenced by Shakespeare in his work and another point as to the shaping of his characters. It is influenced in the way Plutarch defines the characters that surround Caesar. So he puts them in the work according to how they are projected through Plutarch's work. In his particular work and other works he is influenced by the Renaissance, but also by the freedom of the ancient Greek spirit, elements that we find in the works of Plutarch.

The plot in this work also defines its subject. The subject in Shakespeare's particular work is centered in Julius Caesar and his murder by the conspirators, with his main consort, Brutus. In a wider context, these two faces are confronted by Caesar and Brutus, who represented two different things, with two different central axes. Behind all, the thirst for power on a different 
scale for each of the two protagonists.

The central aim of Caesar seems to have been the establishment of tyranny in Rome in order to completely eradicate democracy and to make Rome and its sovereignty. We distinguish from his actions an overwhelming ambition by not wanting to lose the struggles he carries by giving everything to accomplish, bringing together the axioms one by one. Of course, Caesar's success was many who exploited her to propagate political propaganda against him (Guthrie, 1954: 15-18).

\subsection{Coriolanus}

Coriolanus or Gaios Markos was a Roman politician and general and acted in the $5^{\text {th }}$ century BC (Plutarch, Koriolanos, 251: 1-39). His name took it from the city that he conquered in 493 BC, which is called Koriolis (Titos Livios, Ad urbe condita, 2.33). This city belonged to Volsky, where the Romans with them had a strong counter. Even between 500 BC and 338 BC, the Volks and the Romans had constant warfare until the Romans finally defeated the Volsky. So, after the above defeat of the Volcans, he became the leader of the extreme aristocratic of Rome (Plutarch, Koriolanos, 8, 9, 10). In 491 BC, he pissed off, and decided not to divide the grain of Sicily into the Penitentians, caused the people's hatred to his face, and in an assembly of the municipality he was determined to be exiled.

Coriolanus was a great soldier and a man with strong ideals, but he despises the citizens. His extreme perceptions spark a massive outburst and Rome drowns in blood. Being patrician was humiliating and despising the eunuchs, that is, the generally simple people. Of course, the difference between Coriolanus and the rest of the patriarchs lies in the fact that Coriolanus was burning with the crowd and mocker, while most patricians were wary of the people because they had the power of the mob in the back of their minds and feared all sorts of rebellion, so they were interrupted with them. So he allied himself with his enemy to fight against the corrupt political scene in Rome (Plutarch, Koriolanos, 22-29).

Coriolanus, a work of Shakespeare's Creative Period, written in 1607-1608. The sources of this work are taken by Plutarch. Coriolanus is largely based on the Life of Coriolanus in Thomas North's translation of Plutarch's The lives of the noble Grecians and Romans (1579). The wording of Menenius's speech about the body politic is derived from William Camden's Remaines of a greater worke concerning Britaine (1605), where Pope Adrian IV compares a well-run government to a body in which "all parts performed their functions, only the stomach lay idle and consumed all” (Parker, 1994: 17-21): the fable is also alluded to in John of Salisbury's Policraticus (Camden's source) and William Averell's A marvailous combat of contrarieties (1588). Other sources have been suggested, but are less certain. Shakespeare might also have drawn on Livy's $A b$ Urbe condita, as translated by Philemon Holland, and possibly a digest of Livy by Lucius Annaeus Florus; both of these were commonly used texts in Elizabethan schools. Machiavelli's Discourses on Livy were available in manuscript translations, and could also have been used by Shakespeare. He might also have made use of "Plutarch's original source, the Roman antiquities of Dionysius of Halicarnassus, as well as on his own grammar-school knowledge of Roman custom and law" (Parker, 1994: 18).

In particular, this work negotiates the relationship of people - power. The citizens of Rome live in the misery and deception that is being done against them by the rulers and the demagogues. In a city that dies and seeks heroes, a ruler of arrogance, stubborn and brave wins the title of the High of Rome. At the center of this project, pride takes place which is capable of leading to misguided movements leading a whole city to destruction. 


\subsection{Antonios and Cleopatra}

Markus Antonios was born on January 14, $83 \mathrm{BC}$, or in $85 \mathrm{AD}$ and was a Roman general and politician, who played a major role in turning Roman democracy into a Roman empire. He was a supporter of Julius Caesar and served as one of his generals in the conquest of Galatia and in the civil war (Appianos, Civil Wars, 5, 76). In 43 BC created a triumvirate with Octavian and Lepidus to punish Caesar's murderers. Antonios directed Syria to prepare for the war against the Parthians (Plutarch, Antonios, 36). But there was something that delayed him in dealing with the Parthians. This was nothing but a meeting with Cleopatra. Antonios had so much to do with Cleopatra by taking her and going to Alexandria.

Octavianus saw that Antonios in his actions considered Alexandria as the center of the Roman world. At the same time, his relations with his sister Octavia were non-existent because he was fascinated with Cleopatra and not simply fascinated with her, as they were joined by two children. All this led Octavian to propose the Senate in $33 \mathrm{BC}$ against Anthony, and afterwards the Senate, after its own investigation, ended in $32 \mathrm{BC}$ to remove every post from Antonios and to carry out war in Egypt. The naval battle at Aktio took place in 31 BC. Octavianus officially enters Alexandria on 1 August $30 \mathrm{AD}$. (Plutarch, Antonios, 82). Antonios committed suicide and Cleopatra arrived in Rome. Cleopatra's death is a mystery, but according to the signs found in her body, her death indicates cobra sting. Her death was attributed to suicide (Virgilius, Aeneid, VIII, 696-697).

Antonios and Cleopatra was the $5^{\text {th }}$ tragedy in turn of Shakespeare, which was written in 1607 and published in 1623 (Barroll, 1965: 115-62). It is the ultimate tragedy because we have to do with the poetic maturity of the poet, which has reached the highest degree, so the performance of the two central figures is clear. In particular, this work deals with the original sin and can be considered as the opposite of the work of Romeus and Juliet, because the first love he goes after death.

The plot is based on Thomas North's translation of Plutarch's Lives and follows the relationship between Cleopatra and Markus Antonios from the time of the Sicilian revolt to Cleopatra's suicide during the Final War of the Roman Republic. The major antagonist is Octavius Caesar, one of Antonios' fellow triumvirs of the Second Triumvirate and the first emperor of the Roman Empire. The tragedy is mainly set in Rome and Egypt and is characterized by swift shifts in geographical location and linguistic register as it alternates between sensual, imaginative Alexandria and a more pragmatic, austere Rome (Neill, 1994: 45). Also in his work he makes a correlation of the history of Antonios and Cleopatra, with the history of Dides and Aeneas, influenced by the Virgilius of Aeneid.

This work is governed by a multifaceted plot as it involves love (namely the love of the two central heroes of the work, Antonios and Cleopatra) and death, two different things that inevitably look like this work. Here we meet a mature love, the love of Anthonios and Cleopatra. These two heroes are mature, conscious, so their love becomes another dimension, they are not young, dreamlike like Romeo and Juliet (Bevington, 1990: 12-14).

\section{Shakespeare's influence}

The 19th century is the age of Shakespeare's internationalization. The translations of his entire works into foreign languages began after the middle of the $18^{\text {th }}$ century, with the first German and French host languages in which they were released multi-volume editions between 1760 and 1785 . It would not be an exaggeration to say that in the Tolstoy century, Shakespeare is the dominant influence of dramatic writers and writers in general: from one end of Europe to the other, some consider him to be demigods, all in the cultural centers such as Paris or Vienna or even in the region such as Rome or Athens try to imitate him and, if possible, reach him. 
And so it does not seem to us that Tolstoy, like many other compatriots, has been involved with Shakespeare, but otherwise. While Pushkin, Turgeniev and Dostoevsky were overflowing with admiration, he was immersed in doubt. Tolstoy carefully asks the question of why Shakespeare is so important and is retreating to de-rupt it. Tolstoy tries to spot the moral perpetrator of Shakespeare's everyday worship. Thus, the greatest "conqueror" is none other than Goethe (1749-1832) who imposed his opinion on aesthetic issues in his errand proclaimed Shakespeare a great poet.

As much as one disagrees with many of Tolstoy's tentative remarks, we would all agree today that Shakespeare's cultural sovereignty begins in 18th century England, which makes him a flagship of the culture of a Thracian colonial world superpower. Then, in fact, the Germans, with their predecessor Goethe embracing Shakespeare, like the French romantics, and beyond that the English poet's progress is steadily rising to this day.

\section{Acknowledgements}

This research did not receive any specific grant from funding agencies in the public commercial, or not-for-profit sectors.

The authors declare no competing interests.

\section{References}

Barroll, J. (1965). The chronology of Shakespeare's Jacobean plays and the dating of Antony and Cleopatra. In: G. R. Smith (Ed.), Essays on Shakespeare (pp. 115-162). University Park. Penn State University Press. Pennsylvania.

Bevington, D. (Ed.) (1990). Antony and Cleopatra. Cambridge: Cambridge University Press.

Haldon, J. F. (2003). Byzantium in the seventh century. Cambridge: Cambridge University Press.

Carr, J. (2015). Fighting emperors of Byzantium. South Yorkshire: Pen \& Sword.

Chambers, E. K. (1923). The Elizabethan stage. Oxford: Clarendon Press.

Cook, A. J. (1981). The privileged playgoers of Shakespeare's London. Princeton: Princeton University Press.

Creek, M. (2014). The complete work of William Shakespeare. New York: Race Point Publishing.

Crabbe, A. (1981). Structure and content in Ovid's Metamorphoses, ANRW 2, 31(4), 274-327.

Gibbon, E. (1932). The history of the decline and fall of the Roman Empire. New York: The Modern Library.

Craig, L. H. (1954). Of philosophers and kings: Political philosophy in Shakespeare's "Macbeth" and "King Lear". Toronto: University of Toronto Press.

Guthrie, T. (2003). Julius Caesar. Toronto: Clarke Irwin \& Company LTD.

Kastan, D. S. (1999). Shakespeare after theory. London: Routledge.

Lippincott, J. B. (1913). The tragedie of Iulius Caesar. Lippincott J. B. \& Co. Philadelphia.

Mowat, B. (2014). Titus Andronicus. Oxford: Oxford University Press.

Neill, M. (Ed.) (1994). Antony and Cleopatra. Oxford: Oxford University Press.

Parker, R.B. (Ed.) (1994). Coriolanus. Oxford: Oxford University Press.

Sonnestatter, S. (2008). The construction of feminity in Shakespeare's TITUS ANDRONICUS. Universitat 
I.-S. Kotsori \& K. Manolis - The Influence of Roman History on Shakespeare's Works

Augsburg.

Taylor, G. (1994). Forms of opposition: Shakespeare and Middleton. English Literary Renaissance, 24(2), 283-314.

Von Albrecht, M. (1997). Historia de La Literatura Romana [History of Roman literature]. Barcelona: Herder.

Wells, S. (1997). Shakespeare: A life in drama. New York: W. W. Norton. 